\title{
Institutional Quality and Financial Sector Development: Empirical Evidence from Nigeria
}

\author{
Fisayo Fagbemi ${ }^{1}$ and John Oluwasegun Ajibike ${ }^{2}$ \\ ${ }^{1}$ Department of Economics, Obafemi Awolowo University, Ile - Ife, Nigeria \\ ${ }^{2}$ Department of Banking and Finance, The Polytechnic Ibadan, Ibadan, Nigeria
}

\begin{abstract}
In view of the indispensable role of financial sector in both emerging and developing economies, there has been a notable spotlight on the financial sector development over the years in most African countries. Nonetheless, there are only a few studies on this topical issue, particularly for Nigeria. Hence, this study examines the long - run and short - run dynamic relationship between institutional quality and financial development in Nigeria over the period of 1984 - 2015 using Auto-Regressive Distributed Lag (ARDL) bounds test approach to cointegration. Using two different indicators (Private credit and M2) of financial development, the results consistently show that institutional factors do not have significant effect on financial development in the long - run as well as in the short - run. Furthermore, the empirical evidence indicates that regulatory quality and governance system (institutions) do not necessarily contribute to financial development in a feeble institutional environment, specifically in Nigeria. Thus, our findings suggest that whilst weak institutions could increase the risk of limiting the functioning of financial system, good governance and strong institutions are the essential ingredient of financial development in Nigeria. As a consequence, policies aimed at strengthening the quality of institutions and governance should form the major policy thrust of government (policy makers). These could help improving financial sector development in Nigeria.
\end{abstract}

Key Words: Institutional quality, private credit, broad money, financial Development, ARDL Nigeria

\section{Introduction}

In modern economies, financial markets and institutions have been widely viewed as the cornerstone of the economic development process. Specifically, by facilitating a conducive environment for the economy to thrive, a well - functioning financial system is critical in any economy (King and Levine, 1993; McDonald and Schumacher, 2007). This is because of the essential services provided by financial markets and institutions. For instance, they assess, screen and allocate capital, provide markets for economic actors (i.e. government, firms and household) and enhance effective risk management. Thus, the efficient provision of these services would ensure appropriate flows of capital to individuals, firms and promoting economic growth (Levine, 2003 and Rodrik, 2013).

In view of the indispensable role of financial sector in both emerging and developing economies, there has been a notable spotlight on the financial sector development over the years in most African countries, especially in Nigeria. This is evident as successive governments initiated various policy measures with a view to promoting soundness, efficiency and stability of the Nigerian financial sector $^{1}$. These policies include; Structural Adjustment Programs (SAPs) in the late1980s and early 1990s, banking sector consolidation in 2005 and several other programmes. Specifically, the banks' consolidation reform led to the reduction in the number of banks from 89 in 2015 to 20 in 2012. In terms of bank assets and market capitalization, after South Africa, Nigeria has the second largest financial sector, and it is chiefly bank-based (Zhao and Murinde, 2009). In spite of these remedial measures, access to finance and capital has been a significant constraint to Nigerian business growth (KPMG, 2014). Overall, microfinance sector has experienced considerable changes, but it seems not to be on a sustainable path.

Corresponding author: Fisayo Fagbemi, Department of Economics, Obafemi Awolowo University, Ile - Ife, Nigeria. Email: fisay4real@yahoo.com

(c) This article is distributed under the terms of the Creative Commons Attribution License, which permits unrestricted use and redistribution provided that the original author and source are credited. 
In any economy, deficiencies in financial reporting and weak governance which characterized Nigerian economy could be the bane of effective functioning of financial system (Detragiache, Gupta and Tressel, 2005; Siong and Azman - Saini, 2012).

Moreover, considering the two most widely used indicators of financial development in literature (the ratio of private credit to GDP and $m 2$ to GDP (broad money as \% of GDP), given the statistical report (World Development Indicators (WDI), 2017), it is evident that Nigerian financial system is relatively shallow (see figure 1) and also characterized by numerous vulnerabilities. Accordingly, in the figure (1), the maximum values of both indicators (Private
Credit and $m 2$ ) between 1984 and 2016 are 38.39\% and $43.27 \%$ respectively. These deteriorating conditions could be attributed to entrenched institutional framework (weak institutions) in Nigerian economic system. Nigeria's financial markets and institutions operate under an intricate framework of rules, regulations and guidelines that are not wholly well - comprehensible, and do seem to lack a coherent overall structure. These are gaps and weaknesses jeopardizing the proper functioning and governance of the financial system in Nigeria, despite significant improvements in recent years (IMF country report, 2013)².

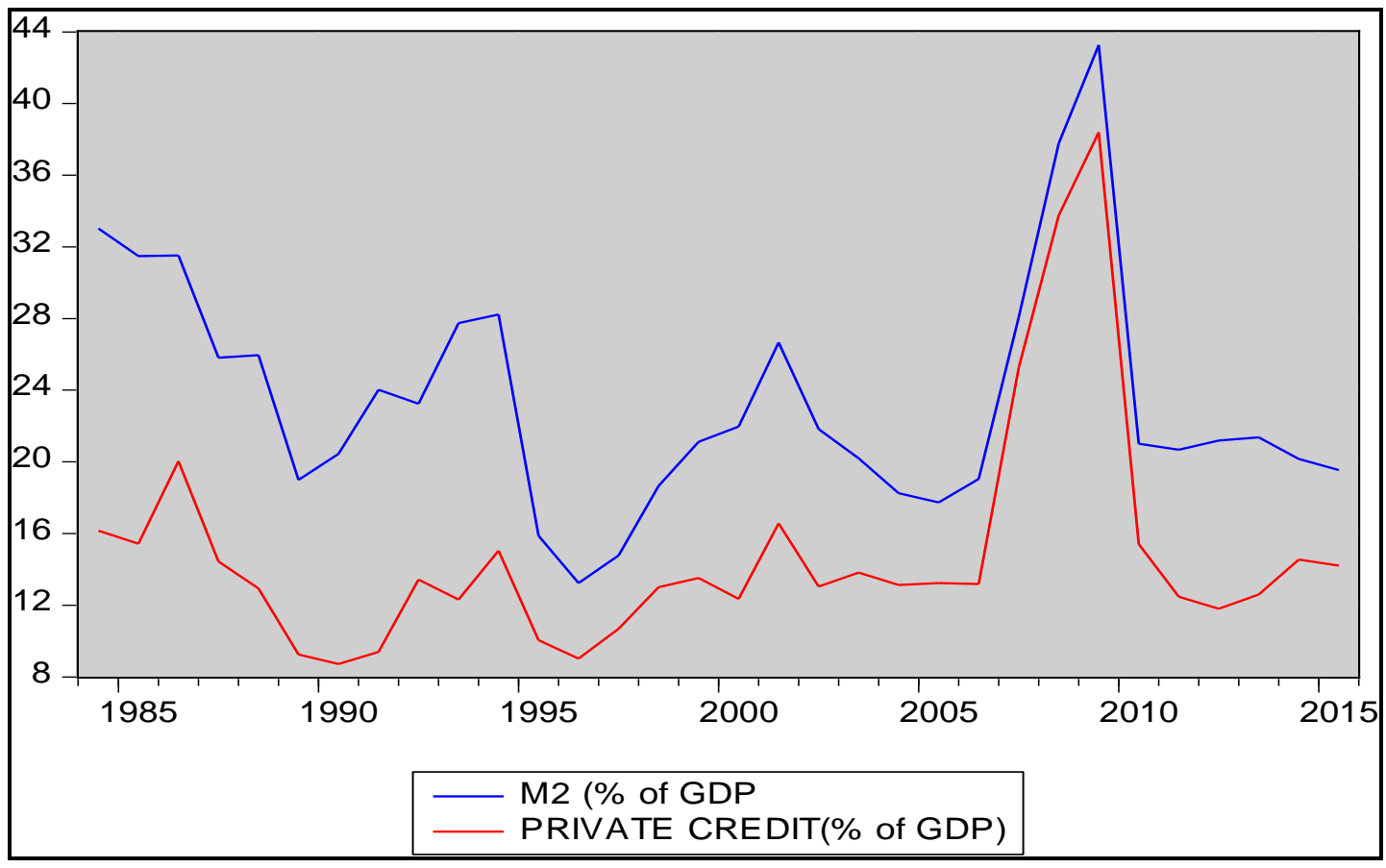

Figure 1: The trend of the Ratio of Private Credit to GDP and $m 2$ to GDP in Nigeria (1984-2016). Source: World Development Indicator (WDI), 2017 and Authors' Computation).

In any economy, sound institutions are the hub of financial sector performance ${ }^{3}$. As a consequence, the plethora of both theoretical and empirical literature show that institutions affect financial sector development (Anayiotos and Toroyan, 2009; Asiama and Mobolaji, 2011; Mbulawa, 2015; Cherif and Gadzar, 2015). However, empirical findings within the context of Nigeria have been limited. Therefore, the extent to which institutional factors influence the level of Nigerian financial sector development has attracted considerable attention among economists. Specifically, the empirical literature on the relation between institutional quality and financial development has been largely dominated by cross country studies, whilst most studies on Nigeria only investigate the nexus between financial development and economic growth and its attendant impact on the economy (Adeniyi et al., 2015; Iheanacho, 2016). In addition, some studies, based on "Finance-Led Growth Hypothesis", focused on the causal relationship between economic growth and financial development basically in view of the leadership crisis and policy challenges (Olayiwola, 2009; Gberevbie, 2011). Whilst the most related study on this topical 
issue examine the impact of institutional reforms on financial sector development in Nigeria (Manasseh, Asogwa and Attama, 2014) using time series data between 1996 and 2011, this study differs to fill the gap by specifically focusing on the relationship between institutional quality and financial development in Nigeria over the period of 1984 2015.

Given the foregoing, the following questions are raised; 1) What is the extent of the influence of institutions on the financial sector development in Nigeria? 2) What has been the effect of institutional quality on financial sector in Nigeria? Hence, the study majorly seeks to investigate the effect of institutional quality on financial sector development in Nigeria (1984 - 2015) using the auto-regressive distributed lag (ARDL) bounds test approach to cointegration analysis.

The article is structured as follows: The immediate section briefly reviews existing literature on financial development. Section 3 presents the empirical methodology. Section 4 presents and discusses the empirical results. Finally, the last section gives the conclusion.

\section{Literature Review}

\section{Theoretical literature}

The early literature has established that financial development is crucial in any economy, as it serves as a catalyst for economic development process. This has been well- documented in the literature by some scholars which includes; Schumpeter (1912) Goldsmith (1969), Mckinnon (1973), Shaw (1973), Levine (2003). However, a new frontier of empirical research is given considerable attention to the factors that determine financial sector development. Theoretically, the potential determinants are; Legal theory of financial development, politics and finance theory, cultural factors and macroeconomic factors such as economic growth, inflation, financial openness etc.

On legal - finance relation, following the law and finance theory of La Porta et al.; 1997), systematically legal practices differ in promoting property rights. In 17th century in England, the common law evolved in order to protect the right of property owner from being dispossessed by the ruling class, which in turn led to good investor protection. In contrast, the development of the French civil law lied in the move to strengthen state power by solidifying the right of the government to centrally enact State rules. Although several attempts were made to check the rule of corrupt courts, the French civil code's rigid nature instead gave rise to abuse of state power for private gains (Beck et al; 2003). Hence, against the background of financial requirement, legal origin maters. As a last resort, to prevent business owners from deferring repayment, some third party embrace the court system. Nonetheless, its distrust of judges, distaste for jurisprudence, and dislike of open judicial disputations tend to make the French legal tradition less responsive to changing conditions, which open up opportunities for infringing property right so as to corner rents accruing from financial services and development.

Considering politics - finance nexus, explaining why some States have been financially underdeveloped, Herger, Hodler and Lobsiger (2007) argue that investors would always rely on the state for contract enforcement and protection of their rights. Thus, any country where there is rampant abuse of authority by corrupt politicians, investor would be averse to investment or put their funds with high risk of confiscation. Therefore, solidifying property right protection is critical in financial transactions. Moreover, according to Clague et al (1996) and Olson (1993), entrenched democratic rules, compared to autocracies, better enhance property rights protection and contract enforcement, hence proliferation of investment. In considering the factors that determine the decision of government to embrace reforms to promote financial sector development, Huang (2006) argues that the level of democracy is one of the significant reasons. More specifically, Pagano and Volpin(2001); Rajan and Zingales (2003); Abiad and Mody, (2005), in their research work on the political economy of financial development, argue that in a closed economy, incumbents benefit from financial repression and the resulting low financial development because it denies potential competitors the financial resources to enter the market.

In another way, culture and finance views emphasis that differences in religion will significantly explain the issue of variations in the development of the financial sector. For instance, in the literature, it has been argued that Catholic and Muslim countries have developed cultures of xenophobia and closed-mindedness that facilitate the construction of powerful, hierarchical political systems that hinder free, competitive financial markets (Landes 1998; Stulz and Williamson, 2001). In addition, on culture-financial development connection, the common stance on this, considering the multiple dimensions of culture, is that as culture develops in the form of greater trust, control and other traits, the attitudes of individuals towards financial market change positively, and they get into greater financial transactions. Thus, results in better 
financial development (Tabellini 2008; Dutta and Mukherjee, 2012).

In view of macroeconomic factors, one of the most important macroeconomic policies that have been widely considered in the literature to be beneficial to financial development is maintaining lower inflation. In contrast, theoretically efficient allocation of resources could be hindered by the process under which predictable increases in inflation affect financial sector effectiveness. Thus, the nexus developed specifically by Huybens and Smith (1998) and Huybens and Smith (1999) stresses that the significant of information asymmetries in the credit market. According to this model, credit market friction is negatively affected by increase in the rate of inflation, which in turn adversely affects financial sector development and thus long -run real activities. These arguments are based on the fact that there is informational friction whose severity is endogenous, such that an increase in inflation rate triggers a fall in the real rate of returns on assets. Therefore, the credit market friction worsens, thereby leading to credit rationing. As such the lender will be discouraged to give out loans to credit seekers due to low real returns as well as increases the adverse selection and moral hazard problems facing lenders. The pool of bad credit risks is overwhelming, asymmetric information problems lead to a decline in investment and economic activities. Consequently, as inflation rises, financial sector gives out only fewer loans leading to inefficient resource allocation and reduced intermediation.

\section{Empirical Literature}

There are many prior studies that have investigated the determinants of financial development. The main differences among these studies arise from the approach and way they are conducted. Some researchers reflect on the effect of a set of variables whereas others examine the impact of a particular variable on financial development. In addition, differences in the methodology employed also accounted for the reason that distinguish these studies. In this section, therefore, the empirical review of the major studies will be carried out in accordance with various identified factors that determine financial development.

As noted in the previous section, recent research efforts have focused on ascertaining the factors that determine financial development (Miletkov and Wintoki, 2008; Asiama and Mobolaji, 2011; Rajan and Zingales, 2003; Huang, 2006). For instance, Beck et al (2003) examine the role of institutional quality in financial development process. Huang (2010) also demonstrates that, at least in the short run, institutional improvements have a positive effect on financial development, and that this is most specifically true for ethnically divided countries, lower income economies and French legal-origin countries. In another significant study, Miskin (2009) demonstrates that globalization is a major factor in facilitating institutional reforms that enhance financial development and economic development in developing countries. He argues that strong institutions are crucial for enhancing financial development as such institutions give rise to effective legal system and efficient regulation of financial activities. Hence, in mediating the role of globalization in financial sector development, institutional quality plays a significant role. More recently, focusing on developed and developing countries, Siong and Azman - Saini (2012) using System GMM show that a strong institutional environment is crucial in explaining financial development. Other researchers that also explain the key role of institutional quality, mostly in developing countries, in financial development are; Trinugroho et al. (2015), Ayadi, et al. (2013), Falahaty and Hook (2010) and Seetanah, et al. (2009).

On the effect of financial openness, a more recent work by Bayar, Akyuz and Erem (2017), based on 9 Central and Eastern European countries (1996-2014), investigate the interaction between financial openness and financial development using cointegration test of Westerlund and Edgerton (2007) and causality test of Dumitrescu and Hurlin (2012). They argue that financial openness positively affects financial development, and there is one way causal direction from openness to financial sector development. In addition, Law (2009) posits that financial openness and trade openness appear to positively impact financial development in developing countries. In his further analysis on whether the impacts lead to strengthened institutional quality or promoting competition, he demonstrates that the channel of institutional quality outstrips the channel of competition in enhancing financial development. Also on openness, using dynamic panel data methods for 43 developing countries (19802001), Demetriades and Law (2006) demonstrate that openness and institutions are major determinants of financial development. Further evidence indicates that whilst liberalisation of both trade and capital flows is less effective in low income countries, it is effective in enhancing financial sector development in middle income countries. An opened economy would be more financially developed than a closed economy, which in turn leads to accelerated growth in the economy as a whole (Rajan and Zingales, 2003). 
On the effect of other policy/macroeconomic variables, using dynamic panel techniques, Naceur and Ghazouani (2007) posit that inflation negatively affects financial development in 11 Middle East and North Africa (MENA) considered between 1979 and 1999. In another study, using dynamic generalized method of moments (GMM), Thai-Ha et al. (2015) examine the determinants of financial development in Asia and the Pacific (1995-2011), and show that economic growth is a major determinant of financial deepening in developed economies. Among others, Cherif and Gazdar (2015), Mahawiya (2015), Elsherif (2015), Motelle (2011), Yu and Gan (2010), Kablan (2010) and Benyah (2010) are studies that show that inflation adversely affects financial development, whilst find that economic growth positively impacts financial transaction and development. These studies are carried out on groups of countries, which are mainly developing economies. In another study, using Granger causality test, Motelle (2011) explores the effect of remittances on financial sector development in Lesotho between 1990 and 2003. The results show that while remittances appear to have long - run effect on financial development, remittances do not grangercause financial development.

Specifically, regarding the need to explore the important role of institutions in financial development process in Nigeria, recent research efforts, although they are not mainly carried out on Nigeria, have identified the nature of institutions in Nigeria. For instance, in the study of Anayiotos and Toroyan (2009), based on sub-Saharan African countries, find that Nigeria has one of the worst institutions (very low institutional quality). They therefore, conclude that weak institutional quality impedes the development of financial sector in Nigeria. Also, Gries and Meierrieksy (2010) for 19 selected Sub-Saharan African countries including Nigeria, suggest that political stability and the protection of property rights are strongly associated with financial sector development. The most related study is the work of Manasseh, Asogwa and Attama (2014) using time series data between 1996 and 2011 examine the effect of institutional reforms on financial sector development in Nigeria. They posit that institutional measures such as government effectiveness regulatory quality and political stability and absence of voice have a strong impact on financial development in Nigeria.

In summary, the empirical literature suggests that although numerous studies have been done regarding the topical issue, focus on the relationship between institutional quality and financial development using the Auto-Regressive Distributed Lag (ARDL) bounds test approach to cointegration analysis, basically in the context of Nigeria has been restricted. Hence the study seeks to contribute to existing literature by filling the gap in knowledge.

\section{Methodology}

\section{Data and data sources}

The study focuses on Nigeria using time series data for the period of $1984-2015$. The scope covers both the period of financial sector crisis and the major financial sector reforms, and it is also determined by the availability of data for the selected variables in the model. Two widely used indicators of financial sector development are incorporated in the model: the ratio of private credit to GDP and $m 2$ to GDP (broad money as \% of GDP). The other three variables used are; institutional indicators (institutional index), while economic growth (Real GDP per capita) and trade openness are included as control variables.

The institutional index represents political risk index ${ }^{4}$ (i.e. investment profile, control of corruption, law and order, democratic accountability, government stability and bureaucratic quality) measuring various dimensions of the political and business environment facing firms operating in any country. It is derived through Principal Component Analysis (PCA) using e-views 9. Trade openness is measured as the ratio of total exports and imports to nominal GDP whilst the real GDP per capita (constant 2010 US\$) represents the economic growth. In the model, the ratio of private credit to GDP is the credit extended to the private sector by commercial banks and other financial institutions, and $m 2$ to GDP represents the expansion of savings and payment activities provided by the financial sector. It is expected that institutional index and real GDP per capita would have direct impact on the financial development, whilst the impact of openness could either be direct or indirect, but this will be determined empirically. The control variables are included because their omission could bias the causal - direction between the institutional quality and financial development. In addition, we include trade openness to reflect the degree of openness of the economy. The financial development indicators as well as macroeconomic data were obtained from world Development Indicators (2017 Edition). However, data for institutional index was obtained from International Country Risk Guide (2016 Edition).

\section{Model specification}


In this study, the model specification is informed by the work of Mickinno (1973), Shaw (1973) and Chinn \& Ito, (2005). Hence, based on the theoretical

$$
F D_{t}=\beta_{0}+\beta_{1} I N T_{t}+\beta_{2} G D P_{t}+\beta_{3} O P E_{t}+\varepsilon_{t}
$$

$F D$ represents financial indicators; $I N T$ is institutional index; GDP is real GDP per capita; $O P E$ is openness. Also, in the model, $t$ is the time period whilst $\varepsilon$ is defined as the error term.

In addition, following Nwani and Bassey Orie (2016), this study employs the Autoregressive Distributed Lag (ARDL-Bounds) testing approach proposed by Pesaran, Shin, and Smith (2001) to examine the cointegration relationship between institutional quality and financial development. In comparison with other cointegration methods, ARDL technique offers several advantages, as whether the review, the financial development relationship is specified in the following empirical model as:

variables used are mutually co-integrated or I(0) or I(1), it is applicable. Also, in small and large sample sizes, with the use of ARDL method, the test results are indeed efficient and consistent (Pesaran, Shin, and Smith (2001). Thus, using ARDL does not require that pretest must be carried out to ascertain the level of stationarity of the variables, although it is necessary to test for unit root because it is not applicable in a situation where the variables exceed I (1). For the variables incorporated in this study, the ARDL model is stated below.

$$
\begin{gathered}
\Delta l n F D_{\mathrm{t}}=\beta_{0}+\sum_{\mathrm{i}=1}^{n} \beta_{1 \mathrm{i}} \Delta F D_{\mathrm{t}-\mathrm{i}}+\sum_{\mathrm{i}=0}^{n} \beta_{2 \mathrm{i}} \Delta I N T_{\mathrm{t}-\mathrm{i}}+\sum_{\mathrm{i}=0}^{n} \beta_{a \mathrm{i}} \Delta G D P_{\mathrm{t}-\mathrm{i}}+\sum_{\mathrm{i}=0}^{n} \beta_{4 \mathrm{i}} \Delta O P E_{\mathrm{t}-\mathrm{i}}+\beta_{5} F D_{\mathrm{t}-1}+\beta_{6} I N T_{\mathrm{t}-1} \\
+\beta_{7} G D P_{\mathrm{t}-1}+\beta_{8} O P E_{\mathrm{t}-1}+\varepsilon_{\mathrm{t}}
\end{gathered}
$$

Where $l n$ is the natural logarithms; $\Delta$ is the first difference operator. For the purpose of investigating the existence of a long-run relationship among the variables, the test requires conducting F-test for the joint significance of all estimated coefficients of lagged variables. Thus it involves the testing of null hypothesis; $\quad H_{0}: \beta_{5}=\beta_{6}=\beta_{7}=\beta_{9}=0 \quad$ (no cointegration) against the alternative hypothesis; $H_{1}: \beta_{5} \neq \beta_{6} \neq \beta_{7} \neq \beta_{9} \neq 0 \quad$ (cointegration). The decision rule: we reject the null hypothesis, if the computed F-statistic > upper bound critical value. However, we do not reject the null hypothesis, if the computed $F$-statistic < the lower bound critical value. The result is inconclusive, if the computed $F$-statistic is in-between the bound. Thus, if the longrelationship among the variables is established, it is followed by constructing an optimal ARDL model specification. The optimal lag length is selected using Akaike Info Criterion (AIC). The general form of ARDL is specified as follows:

$\Delta \ln F D_{\mathrm{t}}=\theta_{0}+\sum_{\mathrm{i}=1}^{n} \delta_{\mathrm{i}} F D_{\mathrm{t}-\mathrm{i}}+\sum_{\mathrm{i}=0}^{n} \theta_{1 \mathrm{i}} I N T_{\mathrm{t}-\mathrm{i}}+\sum_{\mathrm{i}=0}^{n} \theta_{2 \mathrm{i}} G D P_{\mathrm{t}-\mathrm{i}}+\sum_{\mathrm{i}=0}^{n} \theta_{\mathrm{ai}} O P E_{\mathrm{t}-\mathrm{i}}+\varepsilon_{\mathrm{t}}$

Given the model above, whilst within the ARDL framework, after a shock, the error correction model

$$
\Delta l n F D_{\mathrm{t}}=\beta_{0}+\sum_{\mathrm{i}=1}^{n} \beta_{1 \mathrm{i}} \Delta F D_{\mathrm{t}-\mathrm{i}}+\sum_{\mathrm{i}=0}^{n} \beta_{2 \mathrm{i}} \Delta I N T_{\mathrm{t}-\mathrm{i}}+\sum_{\mathrm{i}=0}^{n} \beta_{3 \mathrm{i}} \Delta G D P_{\mathrm{t}-\mathrm{i}}+\sum_{\mathrm{i}=0}^{n} \beta_{4 \mathrm{i}} \Delta O P E_{\mathrm{t}-\mathrm{i}}+\gamma_{\mathrm{i}} E C T_{\mathrm{t}-1}
$$$$
+\varepsilon_{\mathrm{t}}
$$

indicating the speed of adjustment back to long run equilibrium can be estimated. Hence, the error correction model is specified as:

Following the model (3.4), if the coefficient of the $E C T_{t-1}$ is negative and significant, it suggests that any short-run disequilibrium between the dependent and independent variables will adjust towards the long-run equilibrium. 


\section{Empirical Results and Discussion}

Given that time series data are prone to nonstationarity and to justify the use of ARDL bounds test approach to cointegration, as it is not applicable if any of the variable is integrated of order I(2) and beyond, our analysis began with testing for unit roots. As displayed in Table 1 below, for different series, there is a mixed order of integration i.e. I (0) or I(1). Based on the Augmented Dickey Fuller (ADF) and the Phillips-Perron (PP) unit root tests, the rejection of the null hypothesis of the presence of unit root at $5 \%$ significance level are considered stationary and most statistically adequate for the model. Thus, given the unit root test ${ }^{4}$ results presented in Table 1 , the use of ARDL to cointegration approach is justified.

Table 1. Augmented dickey fuller (ADF) and phillips-perron (PP) unit root test results

\begin{tabular}{|c|c|c|c|c|}
\hline Variable & & ADF & & PP \\
\cline { 2 - 5 } \cline { 3 - 5 } & Level & First difference & Level & First difference \\
\hline PCREDIT & $-3.04(1)^{* *}$ & $-4.67(2)^{* * *}$ & -2.03 & $-8.41^{* * *}$ \\
\hline M2 & $-3.55(2)^{* *}$ & $-5.03(0)^{* * *}$ & -2.06 & $-7.35^{* * *}$ \\
\hline$I N T$ & $-1.56(1)$ & $-4.82(0)^{* * *}$ & -1.44 & $-4.82^{* * *}$ \\
\hline GDP & $0.95(0)$ & $-4.22(0)^{* * *}$ & 0.80 & $-4.24^{* * *}$ \\
\hline OPE & $0.15(1)$ & $-7.90(0)^{* * *}$ & -2.09 & $-7.88^{* * *}$ \\
\hline
\end{tabular}

Note: ** and *** denote significance at $5 \%$ and $1 \%$ respectively. Figures in (.) represents lag length selected by AIC criterion. The PP length was selected by Newey-West Band Width.

Accordingly, in this study, the test with unrestricted constant and no trend is adequate. Moreover, ARDL bounds F-test for cointegration is employed to investigate the presence of stable long-run relation between financial development indicators (PCREDIT and $M 2$ ) and the explanatory variables, specifically institutions. Following the estimation, the results of the F-test for both models are presented in Table 2. The table also reports the upper and lower critical values, whilst the F-statistics were compared accordingly. Given the results showed in Table 2, Fstatistics (4.37) of the model, when PCREDIT is used as a proxy for financial development, exceeds 5\% upper bounds critical value of Pesaran et al., (2001), suggesting the rejection of the null hypothesis of no cointegration. Hence, the results show that there is existence of long-run relationship among PCREDIT, institutional quality, GDP and trade openness. In addition, when $M 2$ (dependent variable) is used as proxy for financial sector development, the Fstatistics (4.38) is also greater than the upper (Pesaran et al., 2001) bounds 5\% critical value. This reveals that there is also evidence of a long-run relationship among $M 2$, institutional quality, GDP and trade openness. Thus, these results are in line with the findings of Thai-Hale et al. (2015), Dumitresu and Hurlin (2012) and Miskin (2009). More specifically, in this study, the selection of lags is based on Akaike Info Criterion (AIC) whilst the optimal order is also presented accordingly in Table (2) below. In all, the diagnostic tests validate the results obtained. Figure 2 shows that the CUSUM and CUSUMSQ lie within the critical boundaries, which indicate that the ARDL model coefficients are stable in each of the specifications.

Table 2: Bounds F-tests for cointegration relationship

\begin{tabular}{|c|l|c|c|c|}
\hline Models & F-statistics & Level of Significance & Lower critical values & Upper critical value \\
\hline PCREDIT as dependent variable & $4.37^{* *}$ & & & \\
$(3,0,0,0)$ & & $1 \%$ & 4.29 & 3.61 \\
& & $10 \%$ & 3.23 & 3.35 \\
\hline M2 as dependent variable & $4.38^{* *}$ & & 2.72 & \\
$(3,0,0,3)$ & & & \\
\hline
\end{tabular}

Note: $* *$ represents statistical significance at 5\% level. 
Model of the Ratio of Private Credit to GDP (PCREDIT)
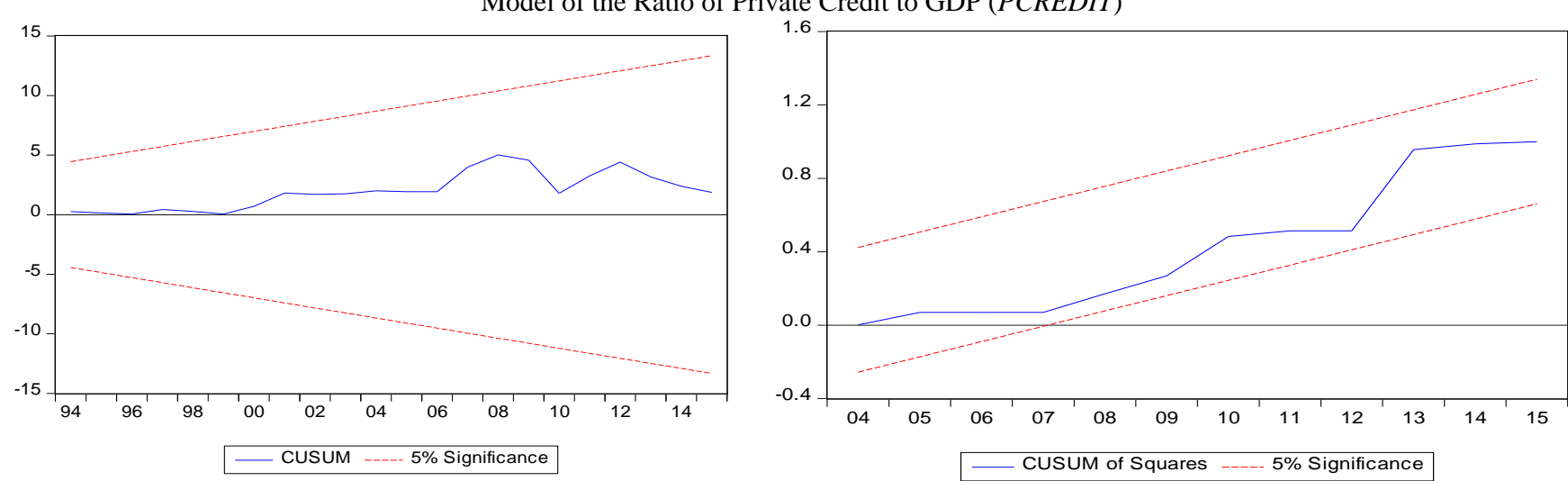

Model of Broad Money (\% of GDP) (M2)
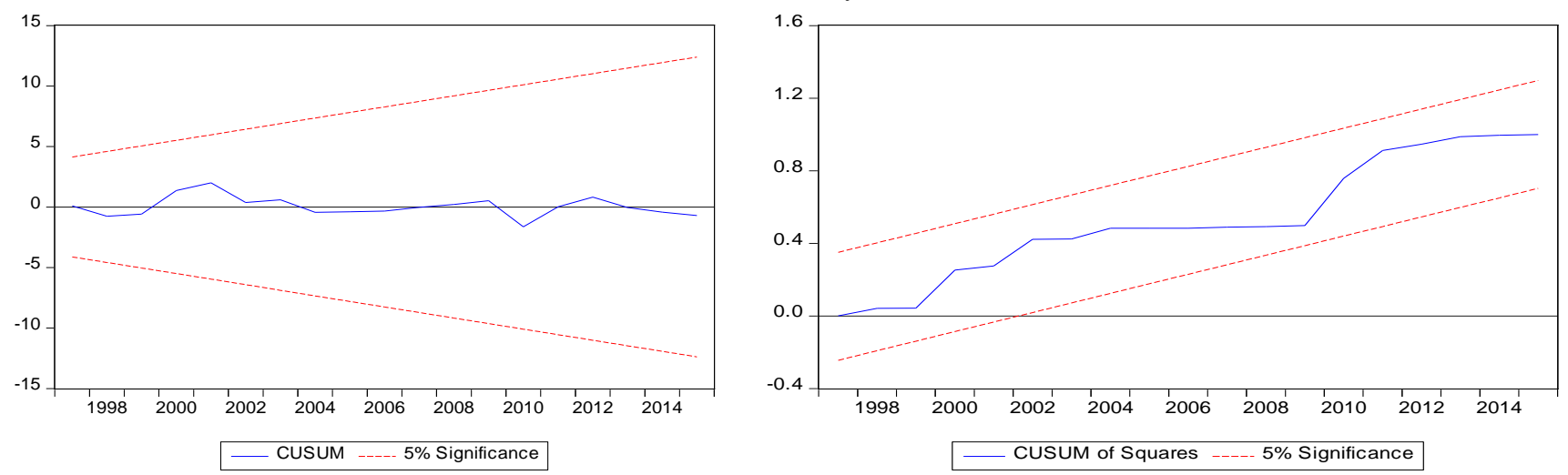

Figure 2. cusum (left) \& cusumsq (right)

The empirical results (in Table 3) of the long-run estimates of the ARDL approach indicate that institutional index which represents all the institutional measures used in the study (such as investment profile, control of corruption, law and order, democratic accountability, government stability and bureaucratic quality) has a positive relationship with financial development (PCREDIT) in the first model (column (i)). However, at any reasonable level of significance, institutional quality is statistically insignificant. This implies that the level of institutional quality does not necessarily translate to financial development, as this could be attributed to very low institutional quality. Also, like the institutional quality, the remaining two independent variables have expected signs (GDP and trade openness). The results further show that, in column (i), there exists a positive relationship between GDP and financial development. The longrun GDP elasticity is 0.012 and is statistically significant at $1 \%$, suggesting that a one per cent increase in GDP will yield 0.012 per cent increase in

financial development. This corroborates the conclusion of Bayar (2016), Elsherif (2015) and Cherif and Gazdar (2015) that there exists a long-run relationship between economic growth and financial development and also GDP is an important determinant of financial sector development. In addition, trade openness is also statistically significant at $5 \%$ and positively related to financial sector development. This means that the influence of trade openness on financial development is positive, such that a one per cent increase in trade openness results to 0.22 per cent increase in financial development. Thus, this is in tandem with the findings of Bayar, Akyuz and Erem (2017); Law (2009) that trade openness is a major determinant of financial development.

Similarly, in the second model (column (ii)), when $M 2$ is used as a proxy for financial development, GDP and trade openness also appear to have a positive effect on financial development, and both are statistically significant at $10 \%$. To be more precise, our results indicate that a one per cent 
increase in GDP and trade openness will lead to 0.49 per cent and 0.06 per cent increase respectively in financial development in the long-run. Regarding our particular variable of interest (quality of institutions), the results obtained are analogous to that of the previous model, in that institutional quality is positively related to financial sector development but found to be insignificant at all levels. Given that the linkage between institutional quality and financial sector development is our major concern, the positive association between quality of institutions and financial development is an indication that strong institutions will substantially enhance financial development. However, in the two model, results show that institutional quality is not statistically significant. Although the significance of institutional quality is sensible and intuitively plausible, analogous to other developing countries, like Sierra Leone, Mozambique, Lesotho, São Tomé and Príncipe, Liberia (see Anayiotos and Toroyan, 2009), institutional factors have very restrained influence on financial development owing to pervasive weak institutions in Nigeria. Thus our findings are consistent with the conclusion of previous studies (Miskin, 2009; Asogwa and Attama, 2014; Gries and Meierrieksy, 2010) that in most developing countries the nature of institutional quality does not necessarily contribute to the development of financial sector when there is no significant improvement in institutional quality.

Table 3. ARDL long run estimates.

\begin{tabular}{|c|c|c|}
\hline Variable & PCREDIT & M2 \\
\cline { 2 - 3 } & Estimated coefficients & (i) \\
\hline Constant & $-12.27(-0.78)$ & $\begin{array}{c}\text { Estimated coefficients } \\
\text { (ii) }\end{array}$ \\
\hline INT & $0.29(0.38)$ & $-0.80(-0.72)$ \\
\hline GDP & $0.012^{* * *(3.29)}$ & $0.01(0.28)$ \\
\hline OPE & $0.22^{* *}(2.26)$ & $0.49 *(2.06)$ \\
\hline Diagnostic Tests & & $0.06^{*}(2.10)$ \\
\hline Ramsey reset test & 0.41 & 0.24 \\
\hline D.W & 2.14 & 2.01 \\
\hline Normality test & 0.75 & 0.73 \\
\hline Serial correlation & 0.23 & 0.06 \\
\hline
\end{tabular}

Note: *, ** and *** indicate statistical significance at $10 \%, 5 \%$ and $1 \%$ respectively, whilst figures in (-) are t-values.

In this study, the final analysis shows the short-run estimated coefficient in Table 4 which are similar to the previous section, as all the variables maintain their expected signs (positive). In both columns, GDP and $M 2$ are positively related to financial development in the short run and also statistically significant, suggesting that both variables have important effect on financial development in the short-run. In stark contrast, our main variable of interest (institutional quality) is not statistically significant in both models, as it is the case in the long-run. This also implies that institutional factors do not necessary contribute to the development of financial sector in the short run. Nonetheless, the coefficient of error - correction term (ER) has expected signs (negative) and statistically significant at $1 \%$ in both models (PCREDIT and M2). More specifically, when PCREDIT is used as an indicator of financial development, the deviation of financial development from the equilibrium values will be corrected by $83 \%$ in the following period, whilst it will be corrected by $76 \%$ when $M 2$ is used as the financial development indicator. Hence, the existence of long - run equilibrium relationship among financial development (FD), institutional quality, $G D P$ and trade openness is confirmed by the significance of ECT. 
Table 4. ARDL short-run Estimates.

\begin{tabular}{|c|c|c|}
\hline Variable & PCREDIT & M2 \\
\cline { 2 - 3 } & $\begin{array}{c}\text { Estimated coefficients } \\
(\mathrm{i})\end{array}$ & $\begin{array}{c}\text { Estimated coefficients } \\
\text { (ii) }\end{array}$ \\
\hline Constant & $-3.53(-0.53)$ & $-0.62(-0.37)$ \\
\hline$\Delta I N T$ & $0.24(0.71)$ & $0.01(0.28)$ \\
\hline$\Delta G D P$ & $0.01^{* *}(2.96)$ & $0.38^{*}(2.11)$ \\
\hline$\Delta O P E$ & $0.18^{* *}(2.50)$ & $0.07^{*}(2.16)$ \\
\hline$E R(-1)$ & $-0.83^{* * *}(-4.38)$ & $-0.76^{* * *}(-3.61)$ \\
\hline Diagnostic Tests & & 0.81 \\
\hline Ramsey reset test & 0.52 & 2.20 \\
\hline D.W & 1.97 & 0.62 \\
\hline Normality test & 0.56 & 0.13 \\
\hline Serial correlation & 0.34 & 0 \\
\hline
\end{tabular}

Note: $*, * *$ and $* * *$ indicate statistical significance at $10 \%, 5 \%$ and $1 \%$ respectively, whilst figures in (-) are t-values.

\section{Conclusion}

In any economy, sound institutions are the hub of financial sector performance. In view of this, many economists (researchers) have developed keen interest in understanding the major determinants of financial sector development. Nonetheless, there are only a few studies on this topical issue, particularly for Nigeria. Hence, it is imperative to understand the linkage between institutional factors and financial development in the context of Nigeria. In particular, this study examines the long - run and short - run dynamic relationship between institutional quality and financial development in Nigeria over the period of 1984 - 2015 using Auto-Regressive Distributed Lag (ARDL) bounds test approach to cointegration analysis.

It is intuitively plausible that institutional factors are crucial for the development of financial sector. However simply because of pervasive weak institutions, in our findings, although there is a direct relationship between institutional quality and financial sector development, institutional quality has very restrained influence on financial development. Specifically, in this study we use two different indicators of financial development, and consistently the results show that institutional factors do not have significant effect on financial development in long run as well as in short - run. Thus, analogous to other developing countries, the nature of institutional quality in Nigeria does not necessarily translate to the development of the financial sector. In contrast, the findings further demonstrate that GDP and trade openness have substantial influence on both the ratio of private credit to GDP and M2 to GDP, as they are used as dependent variables respectively in the short run as well as the in long - run. This empirical evidence could be attributed to the fact that, as one of the developing countries, Nigerian economy is well entrenched in the global finance frontier. Hence, increasing openness of the economy that could emanate from the reduction in trade barriers coupled with improved economic growth will enhance the development of financial sector in Nigeria.

Furthermore, the empirical evidence shows that institutional factors do not have significant effect on financial sector development in a feeble institutional environment such as developing countries, particularly in Nigeria. This implies that, as our results equally show, regulatory quality and governance system do not necessarily contribute to financial development when there is no significant improvement in institutional quality. Overall, weak institutions could increase the risk of limiting the functioning of financial system. Thus, our findings suggest that good governance and institutions are the essential ingredient of financial development in Nigeria. As a consequence, policies aimed at strengthening the quality of institutions and governance should form the top priority of policy makers. This will result to an upturn of Nigeria's financial sector. In addition, trade openness policies (reducing trade barriers) that emerge from this study should also be introduced and implemented by policy makers. The main message of this study is that weak institutions tend to impede the development of financial sector in any economy. On the contrary, strong institutions provide prudential guide for both financial and business activities, which is crucial for financial sector performance. 


\section{Notes}

1. The Nigerian financial sector is grouped into two namely; the informal sector and the formal financial sector. The informal sector consists of the thrifts and savings associations, local money lenders etc. The formal financial system consist of the capital and money market institutions (banks and non - banks financial institutions.

2. In Nigeria, access to bank credit for SMEs is very low. The country lags significantly behind comparator countries owning to institutional deficiencies (IMF Country Report No. 13/140).

3. Figure 3 (see Appendix) shows the \% change in financial development indicators reflecting the average poor performance of Nigerian financial sector over the years.

4. Political Risk index consists of 12 sub-components: voice and accountability (Military in politics \&Democratic accountability); Political stability and absence of violence (Government stability, internal conflict, External conflict, Religion in politics \& ethnic tensions); Government effectiveness (Bureaucratic quality); Regulatory quality (Investment profile and socio economic conditions); Rule of law (law and order); control of corruption (corruption). In this study, six sub-components are taken from each component (ICRG) and used for the construction of a single measure of institutions.

\section{References}

Abiad, A. \& Mody, A. (2005). Financial Reform: What shakes it? What shapes it?" American Economic Review, 95, 66-88.

Adeniyi, O.; Oyinlola, A.; Omisakin, O. \& Egwaikhide, F.O. (2015). Financial development and economic growth in Nigeria: Evidence from threshold modelling. Econ. Anal. Policy, 47, 11-21.

Anayiotos, G.; \& Toroyan, H. (2009). Institutional Factors and Financial Sector Development: Evidence from Sub-Saharan Africa. IMF working paper, WP/09/258.

Asiama, J. P. \& Mobolaji, H. (2011). Trade and Financial Openness, Institutional Quality, and Financial Development in Sub-Sahara Africa (SSA). ICITI, 1694 - 1225.

Ayadi, R.; Arbak, E.; Naceur, S.; \& Groen, W. (2013). Determinants of Financial Development Accross the Mediterranean. MEDPRO Technical Report, No 29.

Bayar, Y.; Akyuz F. \& Erem, I. (2017). Openness and Financial Development in Central and Eastern European Countries Studies in Business and Economics, 12(3).

Beck,. T. (2003). Financial Development and International Trade. Is there a Link? The World Bank Group Working Paper, No. 2608.

Benyah, F. (2010). Determinants of Financial Development: A Focus on African Countries. Jonkoping University

Cherif, M.; \& Gazdar, K. (2015). Macroeconomic and Institutional Determinants of Stock Market
Development in MENA Region: New Results From A Panel Data Analysis. The International Journal of Banking and Finance, Vol.7 (1) 139-159.

Chinn, M.D., \& Ito, H. (2005).What matters for financial development? Capital controls, institutions and interactions. Cambridge MA: NBER. (NBER Working Paper No. 11370).

Clague, C, Keefer, P; Knack, S and Olson, M (1996). Property and Contract Rights in Autocracies and Democracies. Journal of Economic Growth, 1(2), Pp 243-276.

Demetriades, P. \& Law, S. H. (2006). Openness, institutions and financial development. World Economy \& Finance Research Programme, Working Paper, No. WEF 0012, https://ssrn.com/abstract=941387 (11.10.2016).

Detragiache, E. Gupta, P. and Tressel, T. (2005). Finance in Lower Income Countries: An Empirical Exploration. IMF Working Paper 05/167.

Dumitrescu, E., Hurlin, C. (2012). Testing for Granger noncausality in heterogeneous panels, Economic Modelling, Vol.29, No.4, pp.1450 1460.

Dutta, N. and Mukherjee, D. (2012). Is culture a determinant of financial development? Applied Economics Letters, 19:6, 585-590, DOI: 10.1080/13504851.2011.589800.

Elsherif, M. (2015). The Determinants of Financial Development: Empirical Evidence From Egypt. A Multidisciplinary Journal of Global Macro Trends, the Macrotheme Review 4(3).

Falahaty, M.. \& Hook, L. (2010). The Determinants of Financial Development: New Evidence from the Middle East and North Africa Region. Journal of Financial Economics.

Gberevbie, D. E. (2011). Leadership, the financial sector and development in Nigeria. Inkanyiso, Jnl Hum \& Soc Sci, 3(2) pp. 148-158.

Goldsmith, R W. (1969). Financial Structure and Development. New Haven. CT: Yale University Press.

Gries Thomas \& Meierrieksy (2010). Institutional Quality and Financial Development in Sub-Saharan Africa. University of Paderborn, Department of Economics, Warburger Strabe 100, 33098.

Herger, N. Hodler, R. \& Lobsiger, M. (2007). What Determines Financial Development? Culture, Institutions or Trade. Review of World Economics, 144(3), Pp 558-587.

Huang Y (2010). Political institutions and financial development: an empirical study. World Dev 38(12):1667-1677

Huang, W. (2006). Emerging Markets, Financial Openness and Financial Development. University of Bristol, Department of Accounting and Finance, Discussion Paper, 06/588.

Huybens, E. \& Smith, B, D. (1999). Inflation, Financial Markets and Long-run Real Activity. Journal of Monetary Economics, 43(2), Pp 283-315.

Huybens, E. and Smith, B. (1998). Financial market frictions, monetary policy, and capital accumulation in a small open economy. Journal of Economic Theory, vol. 81, no. 2, pp. 353-400. 
Iheanacho, E. (2016). The Impact of Financial Development on Economic Growth in Nigeria: An ARDL Analysis. Economies, MDPI.

IMF (2013). International Monetary Fund Country. IMF Country Report, No. 13/140

Kablan, S. (2010). Banking Efficiency and Financial Development in Sub-Sahara Africa. IMF, WP No. 10136

King R.G. and Levine R. (1993). Finance and Growth: Schumpeter Might Be Right. The Quarterly Journal of Economics, 108(3), 717-737.

KPMG. (2014). Banking in Sub-Saharan Africa. Sector Report

La Porta, R.; Lopez-de-Silanes, F.; Shleifer, A.; \& Vishny, R. (1997). Legal Determinants of External Finance. Journal of Finance, 52(3), pp. 1131-1150.

Landes, D. (1998). The Wealth and Poverty of Nations. New York, NY: W.W. Norton.

Law S. H. \& Azman-Saini W.N.W. (2012). Institutional Quality, Governance, and Financial Development. Economics of Governance 13(3).

Law, S.H. (2009). Trade openness, capital flows and financial development in developing economies. International Economic Journal, Vol.23, No.3, pp.409-426.

Levine, R. (2003). More on Finance and Growth: More Finance, More Growth? Federal Reserve Bank of St. Louis Review, 85 (4), 31-46.

Mahawiya, S. (2015). Financial Sector Development, Inflation and Trade Openness: A Comparative Panel Study of ECOWAS and SADC. Economic Research Southern Africa (ERSA), WP 528.

Manasseh, C. O.; Asogwa, F. O. \& Attama, M. I. (2014). Financial Sector Development: Evidence from Institutional Reforms in Nigeria. Research Journal of Finance and Accounting, 2222-1697, 2222-2847, Vol.5, No.15.

Mbulawa, S. (2015). Determinants of Financial Development in Southern Africa Development Community (SADC): Do Institutions Matter? European Journal of Accounting Auditing and Finance Research, Vol.3, No.6, pp.39-62.

McDonald, C. A.; \& L. B. Schumacher (2007). Financial Deepening in Sub-Saharan Africa: Empirical Evidence on the Role of Creditor Rights Protection and Information Sharing. IMF, WP, No. 203.

McKinnon, R.I. (1973). Money and Capital in Economic Development. Washington, DC: Brookings Institution.

Miletkov, M. \& Wintoki B. M. (2008). Legal Institutions, Democracy and Financial Sector Development. Advances in Financial Economics. F30, N20, 043.

Mishkin; F.S. (2009). Globalization and financial development. J Dev Econ 89(2):164-169.

Motelle, S. (2011). The Role of Remittances in Financial Development in Lesotho: Evidence from Alternative Measures of Financial Development. Journal of Development and Agricultural Economics, Vol. 3(6), pp.241-251.

Naceur, S. B. \& Ghazouani, S. (2007). Stock Markets, banks and Economic Growth: Empirical Evidence from the MENA Region. Research in International Business and Finance, 21(2) Pp 207-315
Olayiwola, W. K. (2009). Practice and standard of corporate governance in the Nigerian banking industry. A paper presented at the international conference on corporate governance. Organized by Covenant University and FISL international UK. Covenant University Learning Resource Centre.

Olson, M. (1993). Dictatorship, Democracy, and Development. American Political Science Review, 87, 567-576.

Pagano, M. \& Volpin, P (2001). The Political Economy of Finance. Oxford Review of Economic Policy, 17 (4), Pp. 502-519.

Pesaran, M. H., Shin, Y., \& Smith, R. (2001). Bounds testing approaches to the analysis of level relationship. Journal of Applied Econometrics, 16(3), 289-326.

Rajan, R. and Zingales, L. (2003). The great reversals: the politics of financial development in the twentieth century. Journal of Financial Economics, 69(1), 5-50.

Rodrik, D. (2013). Structural Change, Fundamentals, and Growth: An overview. School of Social Science, Institute of Advanced Studies.

Schumpeter, J. (1912). Theorie der wirtschaftlichen Entwicklung. Leizpzig: Duncker and Humblot: The Theory of Economic Development; An Inquiry into Profits, Capital, Credit, Interest, and the Business Cycle, Translated by Redvers Opie. Cambridge, Mass.: Harvard University Press, 1934].

Seetanah, B.; Padachi, K.; Hosany, J.; \& Seetanah, H. (2009). Determinants of Financial Development: The Case for Mauritius. Journal of Economic Studies, 37(2), 124-134.

Sharma, P. (2008). Financial Development in Fiji. Griffith University; Griffith Business School, Department of Accounting Finance and Economics.

Shaw, E. (1973). Financial Deepening in Economic Development. New York: Oxford University Press.

Stulz, R. M. \& Williamson, R. (2003). Culture, Openness and Finance. Journal of Financial Economics, 70(3) Pp 313-349.

Tabellini, G. (2008). Presidential address: institutions and culture. Journal of the European Economic Association, 6, 255-94.

Thai-Ha L. Kim, J.; \& Lee, M. (2015). Institutional Quality, Trade Openness, and Financial Sector Development in Asia: An Empirical Investigation. ADB Economics Working Paper Series, No 452.

Trinugroho, I.; Agusman, A.; Arie_anto, M.; Darsono, D.; \& Tarazi, A. (2015). Determinants of Cross Regional Disparity in Financial Deepening: Evidence from Indonesian provinces. <hal-01114255>.

Westerlund, J. \& Edgerton, D.L. (2007). A panel bootstrap cointegration test. Economics Letters, Vol.97, No.3, pp.185-190.

Yu, H.; \& Gan, P. (2010). The Determinants of Banking Sector Development: Malaysian Experience. International Research Journal of Finance and Economics, 35(1), 34-41.

Zhao, T. (2009), Banks' competition, risk taking and productive efficiency: Evidence from Nigeria's banking reform experiments. University of Stirling, Stirling Economics discussion paper, pp. 2009-2023. 


\section{Appendix}

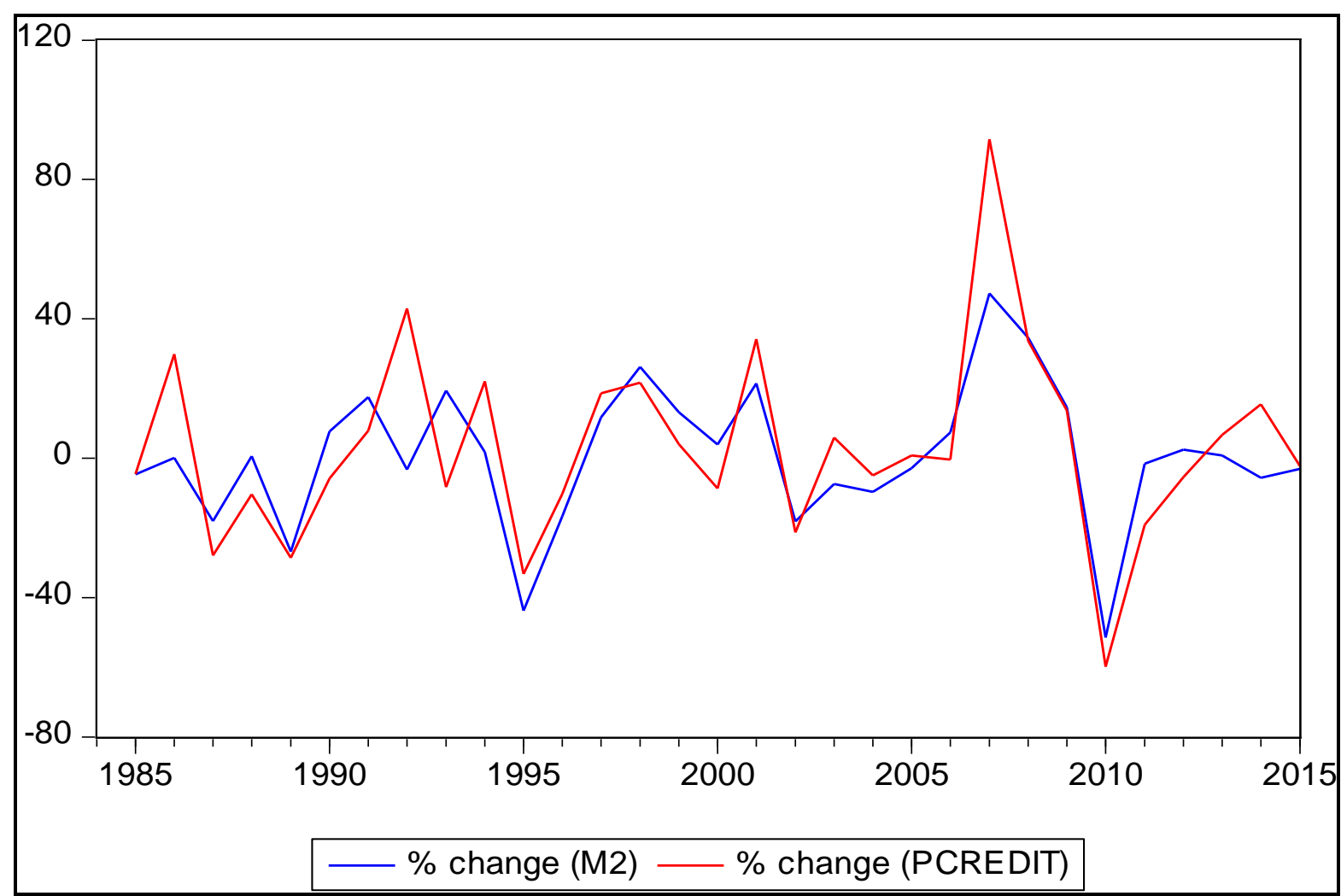

Figure 3: \% change in the ratio of Private credit to GDP and \% in M2 (1984 - 2015) Source: World Development Indicator (WDI), 2017 and Authors' Computation) 